\title{
EFFECT OF FIXED FACTORS AND ESTIMATION OF GENETIC PARAMETERS OF GROWTH TRAITS FOR MOUNTAIN KIDS
}

\section{H. N. Hermiz \\ Prof.}

Coll. Agric., University of Salahaddin profdrhani59@gmail.com

\section{I. Baper}

Assis. Lecturer

\section{ABSTRACT}

Body weights at birth (469), weaning (394) and at six month of age (358) for kids utilized in this study were raised at private project in Duhok governorate, Iraq during two kidding season (2016-2017) and (2017-2018). GLM within SAS programme was used to analyze the data which include the fixed effects (age of doe, year and season of kidding, sex of kid and type of birth, regression on doe weight at kidding, and the regression of later weights of kids on earlier weights) influencing the studied traits. Restricted Maximum Likelihood Method was used to estimate repeatability, heritability, genetic and phenotypic correlations after adjusting the records for fixed effects. Variance components of random effects were tested for positive definite. Overall mean of weights at birth (BWT), weaning (WWT) and 6 month of age (WT6M) were 2.92, 15.32 and $24.45 \mathrm{~kg}$, respectively. Differences among groups of age of doe in all studied traits were not significant, while year of kidding and sex of kid affect all traits significantly (p<0.01). Season of kidding affect BWT and WWT significantly $(\mathbf{P}<0.01)$. Single born kids were heavier $(P<0.01)$ than twins in BWT only. Regression of BWT on doe weight at kidding $(0.033 \mathrm{~kg} / \mathrm{kg})$ was significant $(P<0.01)$, while the regressions of WWT and WT6M were not significant. The regression coefficients of WWT on BWT $(1.906 \mathrm{~kg} / \mathrm{kg})$ and of WT6M on WWT $(0.835 \mathrm{~kg} / \mathrm{kg})$ were highly significant $(P<0.01)$. Repeatability estimates for BWT, WWT and WT6M were $0.47,0.45$ and 0.35 , respectively; on the same order the estimates of heritability were $0.41,0.61$ and 0.79. Genetic correlations between BWT with each of WWT (0.45) and WT6M (0.55), and between WWT and WT6M (0.68) were highly significant. All phenotypic correlations between each pair of body weights were higher than genetic correlations and ranged between 0.48 and 0.73 .

Key words: body weight, goat, heritability, repeatability, genetic correlation.

* Part of Ph.D. Dissertation of the $2^{\text {nd }}$ author

هرمز و بابير

1550-1542:(6)50:2019- مجلة العلوم الزراعية العراقية

تأثير العوامل الثابتة و تقدير المعالم الوراثية لصفات النمو فى الجداء الجبلية

$$
\begin{aligned}
& \text { ميفان ابراهيم بابير } \\
& \text { هاني ناصر هرمز } \\
& \text { مدرس مساعد } \\
& \text { أستاذ } \\
& \text { الكلية التقتية في عقرة ، جامعة دهوك التقتية } \\
& \text { كلية الزراعة ، جامعة صلاح الدين }
\end{aligned}
$$

سجلات أوزان الجسم عذد الميلاد (469)، الفطام (394) وعند عمر ستة أثهر (358) للجداء المستعطة في هذه الدراسة تعود للجداء المولودة

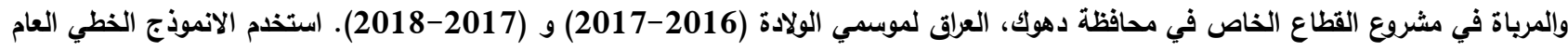
ضمن البرنامج SAS لتحليل البيانات الخاصة بالعوامل الثابتة (عمر الأم، سنة وموسم الولادة، جنس المولود ونوع ولادته، الانحار على وزن الأم عند

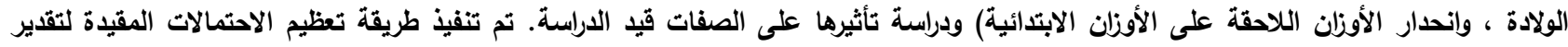

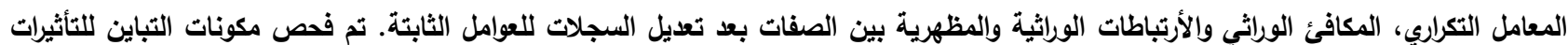

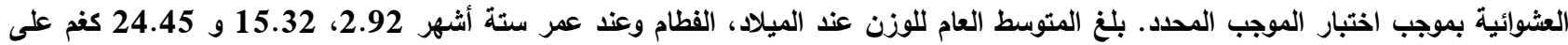

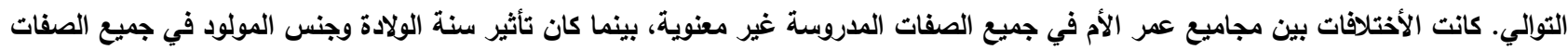

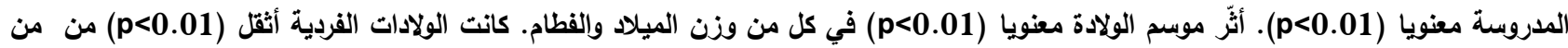

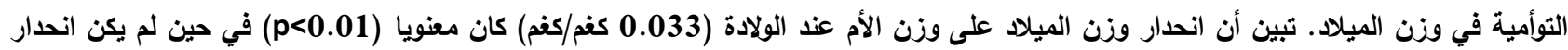

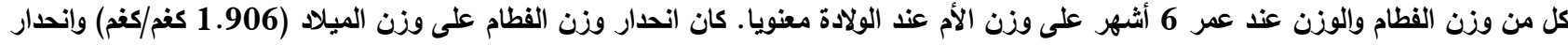

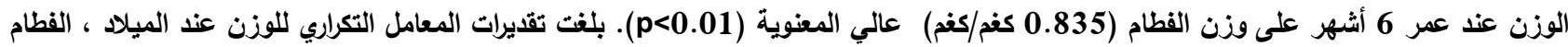
وعند عمر 6 أثشهر 0.47، 0.45 و 0.35 على التوالي ، وينفس الترتيب بلغت تقديرات المكافئ الوراثي 0.41، 0.61 و 0.79. كانت الارتباطات

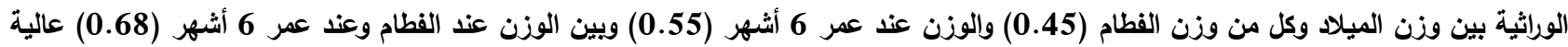
المعنوية. كانت جميع الأرتباطات المظهرية بين كل زوج من الصفات أعلى من الأرتباطات الوراثية وتراوحت بين

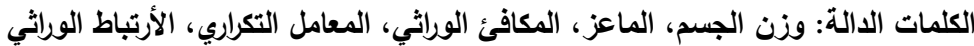

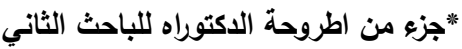




\section{INTRODUCTION}

Goat is an important multipurpose animals and there are no religious barriers to the consumption of goat meat and skins are very valuable by product (52), and considered as important domestic animals in many parts of the world, including Iraq, because of their adaptability to different environmental conditions (19), and utilizing poor quality feed stuffs (15). Growth of kids from birth to marketing age or for replacement is trait of great economic importance and required particular attention for increasing total goat productivity (27). Goat had received relatively little scientific attention when compared with sheep and cattle (58). However, there is a worldwide tendency for rapid increase in demand for goat meat (54) due to several reasons including the desire for leaner meat by consumers compared with other types of red meat (45), development of subcutaneous fat is slow in goat (58), a good source of desirable fatty acids, since goat deposit higher polyunsaturated fatty acids than other ruminants (8) and consequently reducing the risk of cardiovascular disease (54). Weight is an important objective in selection, knowledge of the genetic and phenotypic parameters of growth traits upon which selection based, is of great importance (14). The potential for genetic improvement is largely dependent on the heritability of the trait and its genetic relationship with other traits of economic importance upon which some of selection pressure may be applied (14). The accuracy of genetic evaluation of animals can be improved by evaluating animals under standard environmental conditions (23). Breeders aim is to improve animals genetically to increase their income, and this can be achieved by arranging pedigree record, testing the performance and genetic evaluation individually to have the correct decisions in selecting the best animals to be parents of the next generation (37). Estimating of heritability and repeatability after adjusting records of body weight for the fixed effects, and using the relationship matrix is very necessary to maximize the accuracy of predicting values $(18,49)$. The objectives of this study were to analyze non-genetic factors affecting body weights of mountain kids in a flock of local goat raised at Akre, Kurdistan Region, and to estimate the genetic parameters using an accurate method to be able to improve their productivity by breeding beside the suitable management.

\section{MATERIALS AND METHODS}

Records of mountain kids used in this study were obtained from kids born at private project in Raselain Village/ Akre Region/ Duhok governorate, Iraq during two kidding season (2016-2017) and (2017-2018). Body weights of 469, 394 and 358 kids were measured at birth (BWT), weaning (WWT) and 6 month of age (WT6M), respectively. The animals were allowed to graze natural pasture and stubble, straw and ground oak acorns (Quercus aegilops) were providing whenever required. Does were flushed 2 weeks prior to mating season and 2 week prior to the kidding season. While the bucks were insulated from flock and flushed 4 week prior to mating season. The flock was placed on a regular health program including vaccination, drenching and dipping. New born kids were weighted within 24 hours after birth. Data of new born, body weight and age of doe at kidding, sex of kid and type of birth were recorded. Kids were left with their does till weaning ( 3 months) and their monthly body weight till marketing age at 6 month recorded. General Linear Model (GLM) within the statistical programme SAS (50) used to analyze the collected data to estimate the Best Linear Unbiased Estimates (BLUE) of fixed effects, as well as Restricted Maximum Likelihood (REML) method (44) to estimate the Best Linear Unbiased Predictions (BLUP) of variance components for random effects. The following mixed model assumed for kid's body weight at birth, weaning and at 6months old expressed in matrix notation:

$$
\mathbf{Y}={ }^{7} \boldsymbol{\Sigma} \mathbf{X}_{\mathbf{i}} \mathbf{b}_{\mathbf{i}}+\mathbf{Z u}+\mathbf{e}
$$

$\mathbf{i}=\mathbf{1}$

Where:

$\mathrm{Y}$ : is $\mathrm{N} * 1$ vector of observation,

7

$\Sigma X_{i} b_{i}$ : is the fixed effects, and it's components

$\mathrm{i}=1$ as follows:

$\mathrm{X} 1$ : is a vector of ones of length equal to the number of observation, 
$\mathrm{X} 2$ : is a matrix consisting of 0 and 1 , represent presence or absence the age of doe with dimension of $\mathrm{N}^{*} 4(2.5,3.5,4.5$ and 5.5 year), $=$

X3: is a matrix consisting of 0 and 1 , represent presence or absence the year of kidding with dimension of $\mathrm{N}^{*} 2$ (2016-2017 and 2017-2018),

$\mathrm{X} 4$ : is a matrix consisting of 0 and 1 , represent presence or absence the season of kidding with dimension of $\mathrm{N}^{*} 2$ (winter and spring),

X5: is a matrix consisting of 0 and 1 , represent presence or absence the sex of kid with dimension of $\mathrm{N}^{*} 2$ (male and female),

X6: is a matrix consisting of 0 and 1, represent presence or absence the type of birth with dimension of $\mathrm{N}^{*} 2$ (single and twin),

$X 7:$ is a matrix with dimension of $N^{*} 1$, represent the regression on doe weight at kidding

b1: $\quad$ represents the overall mean of the flock

b2: is a vector of age of doe effects

b3: is a vector of year of kidding effects

b4: $\quad$ is a vector of season of kidding effects

b5: $\quad$ is a vector of type of birth effects

b6: $\quad$ is a vector of sex of kid effects

b7: is a constant for regression of weight of doe at kidding.

$\mathrm{Zu}:$ is the random effect, and it's components as follows:

$\mathrm{Z}: \quad$ is a matrix $\left(\mathrm{N}^{*} \mathrm{~S}\right)$ representing the presence of the random effect of buck, Where $\mathrm{S}$ is the number of bucks (23) to estimate genetic and phenotypic variance covariance. Or $N^{*} \mathrm{D}$ matrix represents the presence of does random effects, and $\mathrm{D}$ referred to the number of does (336) to estimate the repeatability of the traits,

$\mathrm{U}$ : is a vector $\left(\mathrm{S}^{*} 1\right)$, represents the effects of the random variable (buck), or ( $\left.D^{*} 1\right)$ vector represents the effects of the random variable (doe).

e: is an unknown non-observable $\mathrm{N}^{*} 1$ vector of error effects associated with each observation assumed to be NID $\left(0, \mathrm{I}^{2} \mathrm{e}\right)$.

The regression of weaning weight on birth weight and of weight at 6 month on weaning weight were added to the models of weaning weight and 6-month weight, respectively. From solving the above equations, Best Linear Unbiased Estimate (BLUE) and Best Linear
Unbiased Prediction (BLUP) were obtained for the fixed and random effects respectively. The Common Intercept Approach (CIA) used to speed the convergence of the REML procedure (51). Variance-covariance (VCV) matrices were built from random effects (buck and error) and tested for positive definiteness, in order to develop reliable estimates and VCV used for genetic parameters should be within the allowable range (22). Repeatability of BWT, WWT and WT6M were also estimated.

\section{RESULTS AND DISCUSSION}

Overall means of BWT, WWT and WT6M were $2.92 \pm 0.03,15.32 \pm 0.14$ and $24.45 \pm 0.22$ $\mathrm{kg}$, respectively (Table 1). Variation in body weight of kids in different breeds could be attributed to the genetic content of parents due to their affect by the doe breed (20) and sire breed (40). Body weights of kids revealed in this study lay within the range $(1.09-4.42 \mathrm{~kg})$ for BWT, $(4.8-23.0 \mathrm{~kg})$ for WWT, and (7.35$26.72 \mathrm{~kg}$ ) for WT6M which found by earlier studies conducted at several countries using different breeds $(5,13,21,26,28,29,30,31$, $33,34,35,38,41,46,55,57)$. Although there was no significant effect for age of doe on all studied traits (Table 2), however with using Scheffe's test to diagnosing the significant differences between the levels of age of doe, it appears that does aging 3.5 years gives kids having significantly higher BWT, while the differences among the kids born from does with different ages were not significant in their WWT and WT6M (Table 1). Such influences could be due to the differences of the doe uterine size (43), as well to the intra-uterine environment, stage of maturation and the size of doe (11). Previously, some studies presented that the effect of doe age on birth weight of their kids was significant, where kids produced by does aged two years were lighter than those produced by older ones until five year $(27,28,29,34)$. On the other hand, other authors reported that there was no significant effect of age of doe on birth weight $(5,32,55)$. The non-significant differences in WWT and WT6M due to age of doe found in this study were similar to those found by Alkass et al. (5), Ince and Koker (32), Hermiz et al. (28 and 29) and Taher (55) in WWT and by Alkass et al. (5), Bingol et al. (12) and Taher (55) in WT6M. Whereas, several 
authors showed that age of doe had significant effect on both WWT and WT6M $(27,34,46)$ using different breeds in several countries, and this effect could be attributed to variation in milk yield and birth weight (43). Kids born during 2017-2018 have significantly $(\mathrm{P}<0.01)$ higher body weights at all ages included in this study (Tables 1 and 2). Such effect could be attributed to availability of quality and quantity of forage as well as some environmental effects like temperature and humidity over years. Earlier studies conducted in several countries using different breeds of goat noticed that year of kidding affect body weights of kids significantly $(7,17,27,34$, 57). However, Bingol et al. (12) reported that the effect of year of kidding on BWT, WWT and WT6M was not significant. Season of kidding affect BWT and WWT significantly $(\mathrm{p}<0.01)$, while its effect on WT6M was not significant (Table 2). From table (1), it was shown that kids born in spring have significantly higher BWT, while kids born in winter have significantly higher WWT. Such effects of season of kidding reflect the differences in the availability of good quality and quantity of feeds during gestation period (56) and lactation period. The kids born in cool and wet season of the year were significantly heavier in weight than those born in the hot season (16). The most desirable season of kidding is from January to April; which coincides with winter and spring seasons where the temperatures are appropriate and natural grazing land are available. Similarly many authors used various breeds of goat and found that season of kidding had a significant effect on BWT (10, $28)$, as well on WWT $(13,21,35,42)$. Also, Al-Barzinji (2) founded that, Maraz Cashmere kids at weaning weight in spring are heavier $(16.08 \mathrm{~kg})$ than those born in winter $(10.436$ $\mathrm{kg}$ ). On other hand, other studies recorded that kidding season had no-significant effect on BWT $(1,21,56)$, and on WWT $(10,14)$. The non-significant effect of season on WT6M also noticed earlier by Bedhane et al. (10) and Hermiz et al. (28). However, it supposed that weight of kids at 6 months expressed to be affected significantly by kidding season according to Hasan et al. (21). Sex of kidding had a significant effect on all studied traits
$(\mathrm{P}<0.01)$, where males surpassed the females by $0.16,0.96$ and $1.84 \mathrm{~kg}$ in their BWT, WWT and WT6M respectively (Tables 1 and 2). Such differences in the birth weight could be due to the characteristic that weight of cotyledons in males were $10.5 \%$ heavier than females (47), and the differences in WWT and WT6M could be attributed to hormonal differences between them and their resultant effects on growth (43). It is generally accepted by many researchers that male kids were greater than female kids significantly in their body weights at birth $(5,12,13,17,21,25,27$, $29,33,41,42,46,57)$; and at weaning $(2,13$, $17,27,29,33,41,46)$; as well at 6 month old $(5,24,27,29,38,41,46,55)$. On the other hand, many researchers showed that the differences between male and female kids were not significant at birth $(26,36)$; and at weaning $(3,5,9,28,36)$; as well at 6 months of age $(3,28)$. Type of birth had significant $(\mathrm{P}<0.01)$ effect on BWT only, and single born kids where heavier than twins in their BWT by $0.79 \mathrm{~kg}$, while the differences between both at WWT and WT6M didn't reveal to the significance level (Tables 1 and 2). In general, kids body weights decreased as litter size increase due to the existence of competition between twins in utero within litters (5). Heaviest weights of single births at later weights in comparison with twin and triple births could be related to their weights at birth (48). Earlier studies reported that single born kids are significantly heavier than twin born kids at birth $(21,25,26,27,41,46,57)$. While other studies didn't noticed the significant effect of type of birth on birth weight of kids $(13,55)$. At weaning, several studies showed the same effect of type of birth as in this study, where differences between singles and twins were not significant $(3,32,36,38,55)$. Whereas, Rashidi et al. (46), Hermiz et al. (27 and 29), Al-Barzinji (2), and Tyagi et al. (57) found that type of birth has significant impact on WWT. The non-significant effect of type of birth on kids body weight at 6 month were showed by many researchers $(27,29,38,55)$. On other hand, Hermiz et al. (26) and Tyagi et al. (57) reported that type of birth affect WT6M significantly. Weight of doe at kidding had a significant effect $(\mathrm{P}<0.01)$ on BWT with a regression coefficient of $0.033 \pm 0.006$ 
(Tables 1 and 2), and agreement with that reported earlier in the significant effect $(4,53)$, while other researchers didn't found any effect of dam at kidding on birth weight $(28,55)$. The effects of doe at kidding on WWT and WT6M were not significant with a regression coefficient of $0.025 \pm 0.002$ and $0.012 \pm 0.003$ $\mathrm{kg} / \mathrm{kg}$ respectively (Tables 1 and 2 ), and were in agreement with that reported by Hermiz et al. (28), while others noticed that dam weight at kidding had significant effect on WWT (27, $34)$ and on WT6M $(9,20)$. The effect of doe weight on growth traits could be described by the dam uterus size or the maturation state of the dam, and through the quantity of milk produced by dam and her ability to nurse her kid(s), and the carry over effect of weight at birth and weight at weaning to subsequent ages (6). Kids birth weight had significant $(\mathrm{P}<0.01)$ effect on WWT with a regression coefficient of $1.906 \pm 0.204 \mathrm{~kg} / \mathrm{kg}$, also kids weaning weight affect WT6M significantly $(\mathrm{P}<0.01)$ and the regression coefficient being $0.835 \pm 0.053$ (Table 1), the positive and significant regressions were in accordance with those reported earlier by Hermiz et al. (27, 28, 29) and Taher, (55). Repeatability estimates for BWT, WWT and WT6M were $0.47,0.45$ and 0.35 respectively (Table 3 ), these finding were lower to that reported by Hermiz et al. (27), Hasan et al. (21) and
Hermiz et al. (28). However, the values revealed in this study indicated that they can be used to improve the body weights of the next productive seasons and it can predict the subsequent performance of animal under stable environmental conditions (39). Estimates of heritability obtained in this study for BWT, WWT and WT6M were 0.41, 0.61 and 0.79 , respectively (Table 3 ), and were within the range reported by Hermiz et al. (27 and 28). Genetic correlations between BWT with each of WWT (0.45) and WT6M (0.55), and between WWT and WT6M (0.68) were all highly significant, also phenotypic correlations between each pair of body weights were higher than genetic correlations and highly significant and ranged between 0.48 and 0.73 (Table 3), the positive and significant genetic and phenotypic correlations were in accordance with those reported earlier $(10 ; 21$, 28). It can be concluded that fixed effects need to be adjusted before estimating genetic parameters in order to perform unbiased comparisons between kids. The positive and high estimates of genetic parameters at early ages indicate that selection of kids depending on their early body weights will improve their body weights at later ages. Hence selection, on the basis of one trait will be expected to cause a positive correlated response to other traits.

Table 1. Least square means \pm standard errors for the effects on body weights at birth, weaning and 6-month old in Mountain kids

\begin{tabular}{|c|c|c|c|c|c|c|}
\hline \multirow{2}{*}{ Factors } & \multicolumn{2}{|c|}{ Birth Weight (kg) } & \multicolumn{2}{|c|}{ Weaning Weight (kg) } & \multicolumn{2}{|c|}{ 6-month weight $(\mathrm{kg})$} \\
\hline & No & Means \pm S.E. & No & Means \pm S.E. & No & Means \pm S.E. \\
\hline Overall mean & 469 & $2.92 \pm 0.03$ & 394 & $15.32 \pm 0.14$ & 358 & $24.45 \pm 0.22$ \\
\hline \multicolumn{7}{|l|}{ Age of doe(years): } \\
\hline 2.5 & 53 & $2.71 \pm 0.08 \mathrm{ab}$ & 44 & $14.04 \pm 0.38$ a & 43 & $24.17 \pm 0.42$ a \\
\hline 3.5 & 146 & $2.73 \pm 0.05 a$ & 123 & $14.59 \pm 0.23 \mathrm{a}$ & 112 & $24.35 \pm 0.27$ a \\
\hline 4.5 & 184 & $2.61 \pm 0.05 b$ & 155 & $14.63 \pm 0.22 \mathrm{a}$ & 138 & $24.44 \pm 0.25$ a \\
\hline 5.5 & 86 & $2.55 \pm 0.07 b$ & 72 & $14.67 \pm 0.32 \mathrm{a}$ & 65 & $24.62 \pm 0.36$ a \\
\hline \multicolumn{7}{|l|}{ Year of kidding: } \\
\hline 2016-2017 & 196 & $2.51 \pm 0.05 b$ & 164 & $13.24 \pm 0.25 b$ & 163 & $22.82 \pm 0.29 b$ \\
\hline 2017-2018 & 273 & $2.79 \pm 0.05 \mathrm{a}$ & 230 & $15.73 \pm 0.23 \mathrm{a}$ & 195 & $25.97 \pm 0.27$ a \\
\hline \multicolumn{7}{|l|}{ Season of kidding: } \\
\hline Winter & 382 & $2.57 \pm 0.04 \mathrm{~b}$ & 323 & $15.00 \pm 0.19 \mathrm{a}$ & 288 & $24.34 \pm 0.20$ a \\
\hline Spring & 87 & $2.73 \pm 0.06 \mathrm{a}$ & 71 & $13.96 \pm 0.28 b$ & 70 & $24.44 \pm 0.32$ a \\
\hline \multicolumn{7}{|l|}{ Sex of kid: } \\
\hline Male & 243 & $2.73 \pm 0.04 a$ & 191 & $14.96 \pm 0.21$ a & 160 & $25.31 \pm 0.25 a$ \\
\hline Female & 226 & $2.57 \pm 0.04 \mathrm{~b}$ & 203 & $14.00 \pm 0.22 \mathrm{~b}$ & 198 & $23.47 \pm 0.26 b$ \\
\hline \multicolumn{7}{|l|}{ Type of birth : } \\
\hline Single & 412 & $3.04 \pm 0.03 a$ & 350 & $14.78 \pm 0.14 a$ & 318 & $24.43 \pm 0.15$ a \\
\hline Twin & 57 & $2.25 \pm 0.07 b$ & 44 & $14.18 \pm 0.35 a$ & 40 & $24.36 \pm 0.38$ a \\
\hline \multicolumn{7}{|l|}{ Regression on : } \\
\hline Doe weight at kidding & 469 & $0.033 \pm 0.006$ & 394 & $0.025 \pm 0.002$ & 358 & $0.012 \pm 0.003$ \\
\hline Kid birth weight & - & - & 394 & $1.906 \pm 0.204$ & - & - \\
\hline Kid weaning weight & - & - & - & - & 358 & $0.835 \pm 0.053$ \\
\hline
\end{tabular}

Means having different letters within each factor/column differ significantly $(P<0.05)$ according to Scheffe's test 
Table 2. Mean squares and test of significance for factors affecting body weights at birth, weaning and 6-month old in Mountain kids.

\begin{tabular}{|c|c|c|c|c|c|c|}
\hline \multirow{2}{*}{ Factors } & \multicolumn{2}{|c|}{ Birth Weight } & \multicolumn{2}{|c|}{ Weaning Weight } & \multicolumn{2}{|c|}{ 6-month weight } \\
\hline & d.f. & Mean squares & d.f. & Mean squares & d.f. & Mean squares \\
\hline Age of doe(years) & 3 & 0.516 & 3 & 3.085 & 3 & 1.149 \\
\hline Year of kidding & 1 & $4.798 * *$ & 1 & $294.186 * *$ & 1 & $359.364 * *$ \\
\hline Season of kidding & 1 & $1.639 * *$ & 1 & $56.509 * *$ & 1 & 0.533 \\
\hline Sex of kid & 1 & $2.811 * *$ & 1 & $86.834 * *$ & 1 & $261.146 * *$ \\
\hline Type of birth & 1 & $29.38 * *$ & 1 & 10.748 & 1 & 0.158 \\
\hline Regression on : & & & & & & \\
\hline Doe weight at kidding & 1 & $8.170 * *$ & 1 & 3.66 & 1 & 0.762 \\
\hline kid birth weight & - & - & $\mathbf{1}$ & $319.926 * *$ & - & - \\
\hline kid weaning weight & - & - & - & - & 1 & $1080.68 * *$ \\
\hline Residual & 460 & 0.245 & 384 & 3.681 & 348 & 4.376 \\
\hline
\end{tabular}

Table 3. Genetic parameters for the body weights at birth, weaning and 6-month old in kids of Mountain Goat

\begin{tabular}{|lllc|}
\hline Traits & Birth weight & Weaning weight & 6-month weight \\
\hline Birth weight & $\mathbf{0 . 4 1}$ & $\mathbf{0 . 4 5} * *$ & $\mathbf{0 . 5 5} * *$ \\
Weaning weight & $\mathbf{0 . 4 8} * *$ & $\mathbf{0 . 6 1}$ & $\mathbf{0 . 6 8} * *$ \\
6-month weight & $0.57 * *$ & $\mathbf{0 . 7 3} * *$ & $\mathbf{0 . 7 9}$ \\
Repeatability & 0.47 & $\mathbf{0 . 4 5}$ & $\mathbf{0 . 3 5}$ \\
\hline
\end{tabular}

The values on, above, and below the diagonal are estimates of heritability, genetic and phenotypic correlations among traits, respectively.

\section{** $\mathbf{P}<0.01$}

\section{REFERENCES}

1. Abdalla, S.A., I.A. Ishag, and A.A. Mohamed-Khair, 2015. Genetic and environmental factors affecting reproduction of Saanen goats raised under Sudan condition. American J. Agric. Sci. 2 (3): 75-79

2. Al-Barzinji, Y.M.S., 2012. Weaning weight and raw fleece yield of maraz Cashmere goat in Iraq Kurdistan. Iraqi J. Agric. Sci., 43 (3): 87-99

3. Alex, R., K.C. Raghavan, and K.A. Mercey, 2010. Prediction of body weight of malabari goats from body measurements under field conditions. J. Vet. Anim. Sci., 41: 21-27

4. Alkass, J.E., and K.Y. Merkhan, 2013. Meriz goat in Kurdistan region/ Iraq: A review. Adv. J. Agric. Res., 1(007): 105-111

5. Alkass, J.E., H.N. Hermiz, and F.S. Badawi, 1996. Growth competition among twin Angora kids. Iraqi J. Agri. Sci., 27 (1): 23-28

6. Asofi, M.K., H.N. Hermiz, and A.A. AlRawi, 1998. Relationships between partial, total milk production and kid growth in Iraqi local goat. IPA J. Agric. Res. 8(2): 308-316

7. Baneh, H., N. Mojtaba, and R. Ghodrat, 2012. Genetic parameter estimates for early growth traits in Naeini goat. Anim. Prod. Sci., 52: $1046-1051$

8. Banskalieva, V., T. Sahlu, and A.L.Goetsch, 2000. Fatty acid composition of goat muscles and fat depots: a review. Small Rumin. Res., 37: 255-268

9. Bazzi, H., and M. Ghazaghi, 2011. Effect of environmental factors on body weight of Sistani goat of different ages. J. Anim. Vet. Adv., 10 (21): 2819-2823

10. Bedhane, M., A. Haile, H. Dadi, and T. Alemu, 2013. Estimates of genetic and phenotypic parameters for growth traits in Arsi-Bale goat in Ethiopia. J. Anim. Sci. Adv. 3(9): 439-448

11. Bhadula, S.K., and P.N. Bhat, 1980. Genetic and non-genetic factors affecting body weights in Muzaffarnagari sheep and their half breeds. Indian J. Anim. Sci., 50(10): 852-856 12. Bingol, M., I. Daskiran, and A. Yilmaz, 2014. A description of growth performances of Norduz kids and milk yield of Norduz goat. Bulgarian J. Agric. Sci. 20 (3): 690-698

13. Das, B., D. Das, A. Aziz, D. Kalit, and T.C. Roy, 2013. Studies on body weights of Assam local and Assam local cross bred goats. Tamilnadu J. Vet. and Anim. Sci., 9(4): 292295

14. Das, S.M., J.E.O. Rege, and M. Shibre, 1996. Phenotypic and genetic parameters of growth traits of Blended goats at Malya, Tanzania. Proceeding of the third biennial Conference of the African Small Ruminant 
Research Network. ILRI. pp: 63-70. Nairobi, Kenya

15. Delgadillo, J.A., and B. Malpaux, 1996. Reproduction of goats in the Tropics and Subtropics. Proc. 6 International Conference on Goats. 2:785-793

16. Deribe, B., and M. Taye, 2013. Evaluation of growth performance of abergele goats under traditional management systems in sekota district, Ethiopia. Pak. J. Biol. Sci. 16 (14): 692-696

17. Deribe, B., M. Tilahun, M. Lakew, N. Belyneh, A. Zegeye, M. Walle, D. Ayichew, S.T. Ali, and S. Abriham, 2015. On station growth performance of crossbred goats (Boer $\times$ Central Highland) at sirinka, Ethiopia. Asian J. Anim. Sci., 9 (6): 454-459

18. Freeman, A.E., 1998. Dairy cattle breeding. $6^{\text {th }}$ World Congress on Genetics Applied to Livestock Production. 12-16, Jan. Armidale, NSW Australia. 23: 293-294

19. Gall, C., 1981. Goat Production. Fletcher and Sons Ltd., London

20. Gebrelul, S., L.S. Sartin, and M. Iheanacho, 1994. Genetic and non-genetic effects on the growth and mortality of Alpine, Nubian and crossbred kids. Small Rumin. Res., 13: 169-176

21. Hasan, F., Jakaria, and A. Gunawan, 2014. Genetic and Phenotypic Parameters of Body Weight in Ettawa Grade Goats. Media petemakan, April 2014, pp. 8-16

22. Hayes, J.F. and W.G. Hill, 1981. Modification of estimates of parameters in the construction of genetic selection indices ('Bending'). Biometrics, 37: 483-493

23. Hermiz, H.N., 1998. Additive and multiplicative adjustment factor for milk Traits in Iraqi Local Goat. Iraqi J. Agri., 3(2): 164173

24. Hermiz, H.N., 2001. Genetic Evaluation of Local Goats and Their Crosses Using some Productive Traits. Ph.D. Dissertation, College of Agriculture, University of Baghdad. (Arabic).

25. Hermiz, H.N., 2005. Genetic evaluation of Iraqi local goats and their crosses depending on their growth rates. Iraqi J. Agric. Sci., 36(6): 181-189

26. Hermiz, H.N., H.J. Al-Amily, and E.A. Assak, 1997. Some genetic and non-genetic parameters for pre weaning growth traits in
Angora goats (Research Note). Dirasat, Agric. Sci., 24 (2): 182-186

27. Hermiz, H.N., J.E. Alkass, A.A. Hobi, and M.K. Asofi, 2009. Genetic and phenotypic parameters of body weights in Iraqi local goat and their crosses with Damascus. The $2^{\text {nd }}$ Kurdistan conference on Biological Sciences University of Duhok. 6-8 May 2008 J. Duhok Univ., 12 (1) special Issue: 189-194

28. Hermiz, H.N., T.R. Al-Khatib, Sh.M. Amin, A.M. Ahmed, and D.A. Hamad, 2014. Genetic and phenotypic parameters for body weights of Shami kids in Erbil-KRG-Iraq. Int. J. Current Res., 6(11): 9482-9485

29. Hermiz, H.N., A.A. Hobi, A.A. AL-Rawi, and M.K. Asofi, 2012. Estimation of hetrosis, direct and maternal genetic effects of body weights of Iraqi local goat and their crosses with Damascus. Proceeding of the $4^{\text {th }}$ Kurdistan conference on biological sciences. University of Duhok 8-10 May, 2012, pp: 191196

30. Hermiz, H.N., A.S. Shaker, T.R. AlKhatib, Sh.M. Ameen, A.M. Ahmed, and D.A. Hamad, 2016. Inheritance of wattle and their effect on twining and some productive traits in Shami goat. International Journal of Advances in Science Engineering and Technology, ISSN: 2321-9009, Vol-4, Iss-3, Spl. Issue-1: 183-185

31. Hermiz, H.N., M. Singh, A.A. Al-Rawi, and J.E. Alkass, 2008. Genetic and phenotypic trends for growth and milk traits of indigenous and exotic breeds of goats and their crosses in Iraq. Egyptian Journal of sheep and goat sciences. 3(2): 1-8

32. Ince, D., and A. Koker, 2011. The effect of estrus synchronization on the reproductive characteristics of Turkish Saanen goats and growth characteristics of kids under extensive condition. African J. Agric. Res., 6 (26): 57155719

33. Ismail, A.M., I.A. Yousif, and Fadlelmoula, 2011. Phenotypic variations in birth and body weights of the Sudanese desert goats. Lives. Res. Rural Dev. 23 (2): 1-5

34. Jawasreh, K.I., 2003. Genetic evaluation of Damascus Goats in Jordan. Ph.D. Dissertation, College of Agriculture, University of Bagdad, Iraq

35. Jimenez-Badillo, M.R., Rodrigues, S., Teixeira, A. and Sanudo, C. (2009). Non- 
genetic factors affecting live weight and daily gain weight in serrana transmontano kids. Span J. Agric. Res., 12(1): 133-150

36. Keskin, M., S. Gül, O. Biçer, and İ. Daşkıran, 2017. Some reproductive, lactation, and kid growth characteristics of Kilis goats under semi intensive conditions. Turk $\mathbf{J}$ Vet Anim. Sci., 41: 248-254

37. Kinghorn, B.P., 1997. Genetic Improvement of Sheep. In: The Ed. L. Piper and A. Ruvinsky. University Press, Cambridge. pp:565-591

38. Mahal, Z., M.A.M.Y. Khandoker, and M.N. Haque, 2013. Effect of non-genetic factors on productive traits of Black Bengal goats. Bangladesh J. Agri. Univ. 11 (1): 79-86 39. Mourad, M., 2001. Estimation of repeatability of milk yield and reproductive traits of Alpine goats under an intensive system of production in Egypt. Small Rumin. Res., 42: 1-4

40. Mourad, M. and M.R. Anous, 1998. Estimates of genetic and phenotypic parameters of some growth traits in Common African and Alpine crossbred goats. Small Rumin. Res., 27: 197-202

41. Msalya, G., V.S. Sonola, P. Ngoda, G.C. Kifaro, and L.O. Eik, 2017. Evaluation of growth, milk, and manure production in Norwegian dairy goats in one highland of Tanzania 30 years after introduction. South African Journal of Animal Science. 47(2):202212

42. Osman, M.A., 2013. Estimates of direct and maternal effects for early growth traits of Zaraibi goats. Egyptian Journal of Sheep and Goat Sciences, 8 (1): 7-14

43. Owen, J.B., 1976. Sheep Production. Bailliere and Tindal, London, UK

44. Patterson, H.D., and R. Thompson, 1971. Recovery of interblock information when block sizes are unequal. Biometrika. 58: 545554

45. Potchoiba, M.J., C. Lu, F. Pinkerton, and T. Sahlu, 1990. Effect of all-milk diet on weight gain, organ development, carcass characteristics and tissue composition, including fatty acids and cholesterol contents of growing male goat. Small Rumin. Res. 3:583-592

46. Rashidi, A., M. Sheikhahmadi, J. Rostamzadeh, and J.N.B. Shrestha, 2008.
Genetic and phenotypic parameter estimates of body weight at different age and yearling fleece weight in markhoz goats. Asian-Aust. J. Anim. Sci., 21(10):1395-1403

47. Rhind, S.M., J.J. Rodinson, and I. McDonald, 1980. Relationship among uterine and placental factors in prolific ewes and their relevance to variations in foetal weight. Anim. Prod., 30: 115-124

48. Robinson, J.J., I. McDonald, C. Fraser, and R.M.J. Croffs, 1977. Studies on reproduction in prolific ewes. I. Growth of the products of conception. J. agric. Sci. Camb., 88: 539-552 49. Sakul, H., W.J. Boylan, and J.N.B. Shrestha, 1999. Animal model evaluation of dairy traits in US sheep breeds, their crosses and three synthetic populations. Small Rumin. Res., 34: 1-9

50. SAS, 2005. SAS/STAT „Usere"s Guide for Personal Computers, Release 8.00.SAS Institute Inc., Cary, NC, USA

51. Schaeffer, L.R., 1979. Notes on Linear Model Theory, Best linear Unbiased Prediction and Variance Component Estimation. University of Guelph, Guelph, Ontario. pp: 1-19

52. Selvam, R., 2018. Genetic and non-genetic factor affecting the birth weight of Boer Grded goats and non-Descript goats. International Journal of Science, Environment and Technology, 7(3):900-904

53. Soundararajan, C., and T. Sivakumar, 2011. Factors affecting birth weight in tellichery kids. Tamilnadu J. Vet. Anim. Sci., 7(2):60-63

54. Stankov, Iv.K., N.A. Todorov, J.E. Mitev, and T.M. Miteva,2002. Study on some qualitative features of meat from young goat of Bulgarian breeds and crossbreeds of goats slaughtered at various ages. Asian-Aust. J. Anim. Science. 15: 283 - 289

55. Taher, M.T. 2017. Genetic and non-genetic Parameters of Some Economic Traits in Maraz Goats. M.Sc. Thesis, College of Agriculture, University of Duhok, Iraq

56. Thiruvenkadan, A.K., M. Murugan, K. Karunanithi, J. Muralidharan, and K. Chinnamani, 2009. Genetic and non genetic factors affecting body weight in tellicherry goats. South African J. Anim. Sci., 39 (supplement1 
57. Tyagi, K.K., M.D. Patel, L.M. Sorathiya, D.P. Kshirsagar, M.V. Patel, and R.B. Thakor, 2015. Growth traits and their interrelation ship in surti goats. Anim. Sci. Rep., 9(3):105-113
58. Warmington, B.J., and A.H. Kirton, 1990. Genetic and non genetic influences on growth and carcass traits of goats. Small Rumin. Res. $3: 147-165$. 